\title{
The Italian Giuseppe Muscatello (1866-1951) and his contributions to our understanding of childhood spina bifida aperta and occulta
}

\author{
Gabrielle G. Tardieu ${ }^{1} \cdot$ Marios Loukas $^{1} \cdot$ Christian Fisahn $^{2}$ • \\ Mohammadali M. Shoja ${ }^{2} \cdot \operatorname{Rod}$ J. Oskouian ${ }^{2} \cdot$ R. Shane Tubbs ${ }^{2}$
}

Received: 13 July 2016 / Accepted: 19 July 2016 / Published online: 28 July 2016

(C) Springer-Verlag Berlin Heidelberg 2016

\section{Introduction}

\section{Early career}

Giuseppe Muscatello (Fig. 1) was born in 1866 on Sicily. He and his wife, Elena, had four children. In 1889, he received his medical degree from the University of Naples [1]. He studied surgery from 1889 to 1892 in Padua. He first worked in Strasbourg, supervised by Georg Albert Lücke, and then at the Institute of Pathology under renowned pathologist, Friedrich Daniel von Recklinghausen [2]. He moved to Berlin where he worked in surgery under Vincenz Czerny and in pathology under Julius Arnold of Arnold-Chiari malformation fame [3].

In 1894, Muscatello returned to Italy and soon after received a degree in teaching Surgical Pathology from the University of

Gabrielle G. Tardieu

gtardieu@sgu.edu

Marios Loukas

mloukas@sgu.edu

Christian Fisahn

Christian.Fisahn@swedish.org

Mohammadali M. Shoja

shojamm@hotmail.com

Rod J. Oskouian

rod.oskouian@swedish.org

R. Shane Tubbs

shanet@seattlesciencefoundation.org

1 Department of Anatomical Sciences, St. George's University, St. George's, GrenadaWI

2 Seattle Science Foundation, Seattle, WA, USA
Turin where he became an assistant at the Institute of General Pathology, which was supervised by Giulio Bizzozero [1]. He also worked at the Mauritian Hospital from 1894 to 1897 (http://www.treccani.it/enciclopedia/giuseppe-muscatello (Dizionario-Biografico)/). After this, Muscatello returned to Naples to work at the Institute of Clinical Pathology and Surgery. In May of 1898, he became Professor of Pathology at the University of Turin, and in 1900, he became director of Surgical Pathology [2].

\section{Later career}

In 1901, Muscatello was nominated by von Recklinghausen for the Nobel Prize in Medicine for his works [4-7] (Ueber die angeborenen Spalten des Schädels und der Wirbelsäule, Über einen nicht gewöhnlichen Fall von Cephalocele und über die postoperative Hydrocephalie, Über die Diagnose der Spina bifida und über die postoperative Hydrocephalie and Studi sul cefalocele e sulla spina bifida) on childhood spina bifida and hydrocephalus (http://www.nobelprize . org/nomination/archive/show.php?id=12566). Although he did not win this prize (this was given to Golgi), he continued to research and publish on spina bifida. In 1902, Muscatello became Professor of Surgical Pathology at the University of Catania. In 1903, he moved to the Faculty of Medicine of Pavia, and in 1906, he was elected Professor of Pathology. In 1906, while retaining his position as chair of Clinical Surgery and Operative Medicine at the University of Modena, he returned to Sicily and taught in Catania as Professor of Pathology [8]. He was appointed Professor of Clinical Surgery and Operative Medicine in 1923. From 1908 to 1910 , he served as chancellor of the University of Catania. He retired and was Professor Emeritus from 1927 to 1937. 


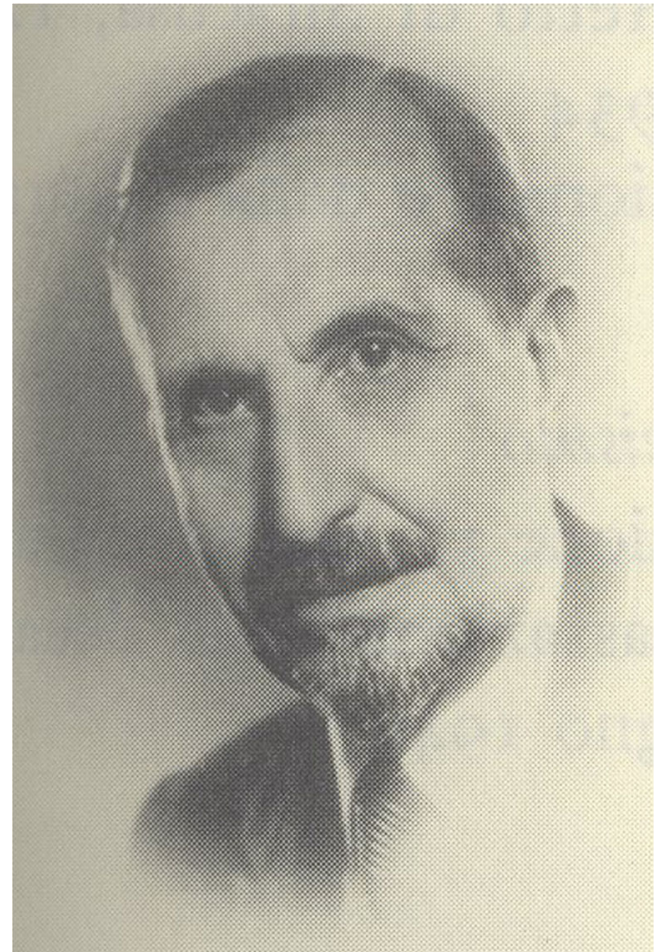

Fig. 1 Photograph of Giuseppe Muscatello (1866-1951). Source: http://dati.camera.it/ocd/persona.rdf/pr10011

Muscatello also performed cancer research and was convinced that it should become its own field of study. In fact, in 1932, in conjunction with the Hospital Vittorio Emanuale II and the University of Catania, he established one of the first cancer centers in Italy. He studied the lymphatics of the diaphragm, empyema, the spleen, and developed techniques for repair of exstrophy of the urinary bladder [7]. He would go on to receive many awards and honors including the Gold Star granted by the Official Order of the Crown of Italy and the Knight Official Order of Ss., Maurice and Lazarus. On August 1, 1951, he died in Catania at the age of 85 years [8] (http://www.treccani.it/enciclopedia/giuseppe-muscatello_ (Dizionario-Biografico)/.

\section{Contributions to understanding spina bifida}

Muscatello described several forms (Fig. 2) of spina bifida including myelomeningocele, meningocele, myelocystocele, and spina bifida occulta. Myelomeningocele was described as "a hernia of the spinal cord with participation of the spinal cord." He developed surgical techniques for treating this pathology but recognized that surgery for rachischisis totalis was unwarranted as these children always died. He also realized that myelomeningoceles most commonly occurred in the lumbosacral region and less often in the cervical and thoracic regions of the spine. Surgically, he often found isolated groups of ectopic ganglion cells within the disorganized nerve roots. He observed that paralysis of the lower limbs, bladder, and the
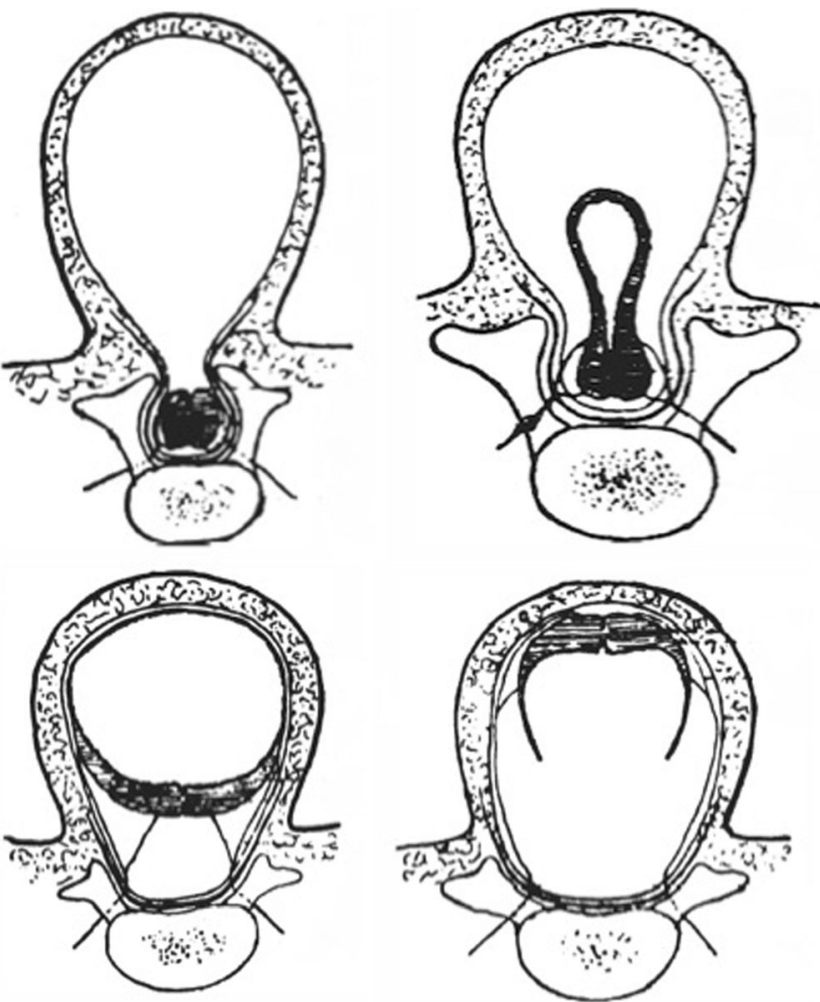

Fig. 2 Examples of the varying degrees of myelodysplasia as demonstrated by Muscatello in his 1894 paper Ueber die angeborenen Spalten des Schädels und der Wirbelsäule

rectum and club feet were very common. However, for meningoceles, especially of the sacral region, he observed that motor function was usually good pre- and post-operatively. He noted that myelocystoceles can be confused with meningoceles and thought that many previously mentioned cases of meningocele were actually myelocystoceles. He found that myelocystoceles were most common in the lumbar region and were rarely found in the neck and even more rarely in the thoracic spine.

Muscatello documented many associated findings with spina bifida including caudal agenesis, kyphoscoliosis, absent radius, increased angulation of the sacrum, caudally displaced conus medullaris (e.g., tethered cord), fused ribs, and anomalous sternum. He also identified syringomyelia in the spinal cords of some patients, and the commonly found hydrocephalus of patients with myelomeningocele was, in his opinion, not enough evidence to suggest that hydrocephalus was the primary lesion leading to this form of spina bifida. He noted that the skin of patients born with spina bifida might have changes such as dark spots (e.g., flat capillary hemangiomas). Muscatello observed that although club feet were commonly seen in patients with myelocystoceles, paralysis of the bladder was uncommon.

Muscatello also described patients with occult spinal dysraphism, e.g., spina bifida occulta. For example, clear examples of split cord malformation were documented with one 
of these found to have an associated dermoid. He found that spina bifida occulta was most commonly encountered in the caudal portion of the spine. For this category of spinal dysraphism, he realized the association between focal hirsutism and underlying anomalies, such as split cord malformation, and observed that some of these cases were hereditary.

\section{Conclusions}

It is the contributions of such historical figures as Muscatello that our present understanding of pathology, such as spina bifida, rests. We believe this to be the first review of his life and contributions to spina bifida in the English language.

\section{Compliance with ethical standards}

Conflict of interest The authors have no conflicts of interest.

\section{References}

1. De Vecchi P (1921) Modern Italian surgery and old universities of Italy. Hoeber, New York

2. Francesco S (1931) In Onore di Giuseppe Muscatello nel XXX Anno di Insegnamento 1901-1930. Antica Libreria Sri, Catania

3. L'Archivio storico del Senato. http://www.senato.it/3065?voce sommario $=35$

4. Muscatello G (1894) Ueber die angeborenen Spalten des Schädels und der Wirbelsäule. Arch klin Chirurgie 48:162-256

5. Muscatello G (1900) Über einen nicht gewöhnlichen Fall von Cephalocele und über die postoperative Hydrocephalie. Archiv fürklinische Chirurgie 68:248-266

6. Muscatello G (1900) Über die Diagnose der Spina bifida und über die postoperative Hydrocephalie. Archiv fürklinische Chirurgie 68: 267-292

7. Muscatello G (1900) Studi sul cefalocele e sulla spina bifida, Catania: Niccolo Giannotta.

8. Enciclopedia treccani. Muscatello, Giuseppe. http://www.treccani. it/enciclopedia/giuseppe-muscatello/ 